\title{
A Study of the Relationship between English Self-concept and Language Learning Strategies
}

\author{
Mingmei Du \\ School of Foreign Language, Shandong University of Finance, 48 Shungeng Road, Jinan, Shandong 250014, China \\ Email: dumingmeizx@163.com
}

\begin{abstract}
The present study concentrated on the relationship between self-concept and language learning strategies. Participants of the study were 157 students from one University in Shandong, China. Quantitative data was collected through two questionnaires. The first one was the revised Chinese version of self-concept scale modified by Pan (2003) from Marsh's (1992) SQDII. Another inventory based on Oxford' classification system of learning strategies (SILL) was used to assess learner's strategy use. By the reliability analysis, it was found that all these coefficients were significantly high, and the two questionnaires were reliable respectively. Based on the detailed analysis of data, some major findings through statistical analysis of SPSS 13.0 were summarized as follows. First of all, the subjects' English self-concept was medium, and the subjects' English pronunciation self-concept was better than their general English self-concept and English speaking self-concept. Second, gender had no significant effects on the general English self-concept and English speaking self-concept. Finally, in terms of the relationship between English self-concept and language learning strategies, by Pearson correlation coefficients and multiple regressions, it was concluded that general English self-concept, English speaking self-concept and English pronunciation self-concept had the highest correlation level with the cognitive strategy, and English pronunciation self-concept had the weakest correlation level with the memory strategy and compensatory strategy. The findings of the study imply that there are some pedagogical implications for English learning and teaching. At the same time, teachers should attach importance to enhancing students' English self-concept level in training their language learning strategies.
\end{abstract}

Index Terms—English self-concept, language learning strategies, relationship

\section{INTRODUCTION}

\section{A. Background of the Study}

Until now, more and more researchers have come to realize the importance of learning strategies and self-concept on ESL/EFL studies. However, the majority of previous studies on language learning strategies have focused mainly on one dominant modifiable variable, occasionally with reference to other unmodifiable variables such as gender and age. Meanwhile, individual learner variables interact with each other in the process of language teaching and learning, so it is necessary to have an overview on their interrelationships that are yet in shortage in reality.

Despite the fact that there have been empirical studies on factors that influence strategy use, and self-concept's influence on learning achievements, little has been done on the relationship between language learning strategies and English self-concept. Thus, more empirical ESL/EFL studies are in great need to explore such interrelationship, especially in different contexts. In recent years, second language learning strategies attract more and more researchers' (Bialystok, 1981b; Leino, 1982; Thomas \& Gadbois, 2007; Watkins \& Gerong, 1999; Wenden, 1991; William \& James, 2002) attention. What makes them concern the aspect so much? According to Ellis (1994), learning strategies are the bridges that connect individual difference and environmental factors and the study results. The individual differences and environmental factors will decide the choice of learning strategies. Based on it, self-concept, as one factor of individual differences, will influence the choice of learning strategies. In Ellis's (1990) model of L2 acquisition, learning strategies play the mediating role between individual learner differences and learning outcomes. Individual learner differences (beliefs, affective states, general factors, and previous learning experiences) together with various situational factors determine the learners' choice of learning strategies.

During the past decades, researchers gave different definitions to self-concept from different perspectives. This study is based on the theory of Shavelson et al. (1976) who claimed that self-concept is "a person's self-perceptions formed through experience with and interpretations of his or her environment. They are influenced especially by evaluations by significant others, reinforcements, and attributions for the individual's own behavior" (p. 413).

Because Oxford's classification is perceived as most easily understood and the most readily accepted (Cheng Xiaotang \& Zheng min, 2002), the present thesis is based on Oxford's classification of language learning strategies(LLSs). Oxford's (1990, pp. 17-22) taxonomy of LLSs is summarized in Table 1.1.

\section{B. Rationale for the Study}

For learners, their optimal learning potential may be compromised in the presence of overly negative self-concept. Self-concept, as a dynamic and motivating set of attitudes held about oneself (Burns, 1979), is promoted as an important 
and focal object within the experience of each individual because of its primacy, centrality, continuity and ubiquity in all aspects of behaviors, mediating as it does in both stimulus and response.

Self-concept has to do with a person's perceptions and evaluations regarding himself or herself. It is a basic requirement for successful cognitive and affective activity. According to Marsh (1990), self-concept is formed through experience with and interpretations of environment. It develops when we are children and gradually learn to identify a self as distinct from others. As we incorporate beliefs, attitudes and memories, new experience and ideas will be affected by the previously existing notion of who we are and by our need to protect this fragile self. In addition, an individual concept of self is especially influenced by evaluations from significant others, reinforcements, and attributions for one's behavior.

Among the factors that influence learners in language learning, learning strategies are important roles. According to Nunan (1991), one of the characteristics of the "good" language learner is an ability to reflect on and articulate the processes underlying their own learning. Effective learners are aware of the processes underlying their own learning and seek to use appropriate learning strategies to control their own learning (Jones et al., 1987). More effective learners differ from less effective ones in their use of strategies (O’Malley \& Chamot, 1990). Students who are designated by their teachers as more effective learners use strategies more frequently, and use a greater variety of strategies than students who are designated as less effective.

Bialystok (1981b) found that Grade 10 and 12 learners of L2 French in Canada varied in the extent to which they believed that language learning involved formal as opposed to functional practice, and that this influenced their choice of strategies.

Wenden \& Rubin (1987) also found that learners who emphasized the importance of learning tended to use cognitive strategies that helped them understand and remember specific items of language, while learners who emphasized the importance of using language employed few learning strategies, relying instead on communication strategies. Learners who stressed personal factors did not manifest any distinct pattern of strategy use.

Bialystok (1981) stated that aptitude was not as influential as learners' beliefs. However, it was possible that learners with enhanced decontextualized language skills (seen by Skehan (1989) as one aspect of aptitude) would be better able to talk about the strategies they used.

Leino (1982) pointed out that learners with high conceptual levels were better at describing their strategies than learners with low conceptual levels. It was possible, then, that learning strategies were related to that part of language aptitude shared with a general intelligence factor.

William and James (2002) pointed out that beginning readers' reported word identification strategies for identifying unfamiliar words in text were examined in relation to reading achievement, reading-related skills, and academic self-perceptions. Children who were participating in a three-year longitudinal study of reading acquisition in a whole language instructional context were placed in two groups according to their reported word identification strategies obtained towards the end of their first year of schooling. Results indicated that children who reported using wordbased strategies showed superior reading and reading-related performance, and reported more positive self-efficacy beliefs in reading and more positive academic self-concepts than children who reported using text-based strategies. The results were discussed in terms of predictions stemming from the different theoretical assumptions about reading acquisition that underlie the code-emphasis and whole language approaches to beginning reading instruction.

Although many researchers from home and abroad have made a lot of research to find out that there are significant differences of using learning strategies between the good learners and losers of examination, the research about individual and environmental factors' influences on learning strategies is little. In China, some research found out that English self-concept can influence learning strategies. Xu Jin and Zhao Jingbo (2006) conducted a survey among 598 medical sophomores of a medical university by using the self-concept questionnaire and strategy inventory of language learning. The results showed that self-concept had significant correlation with language learning strategies. It was concluded that during the training of language learning strategies, importance should be attached to enhancing English self-concept level.

Watkins and Gerong (1999) conducted a test about language of response and the spontaneous self-concept. Responses to the Twenty Statements Test were obtained from 166 Filipino secondary school children asked to respond either in English or Cebuano, their local language. Contrary to the cultural accommodation hypothesis, the respondents did not provide more independent self-references in the English language condition. Examination of responses indicated that when responding in English, the participants, particularly the males, were influenced by the school context. The females tended to provide more relational self-references.

Thomas and Gadbois (2007) examined students' self-esteem and self-concept clarity as well as their tendencies to employ deep- or surface-learning approaches and self-regulate while learning in relation to their self-handicapping tendencies and exam performance. Participants were 161 male and female Canadian, first-year university students. Participants completed a series of questionnaires that measured their self-esteem, self-concept clarity, approaches to learning, self-regulation and reflections on performance prior to and following their exam. The results were that self-handicapping was negatively correlated with self-concept clarity, deep learning, self-regulated learning and exam grades, and positively correlated with surface learning and test anxiety. Regression analyses showed that self-concept clarity, self-regulation, surface-learning and test anxiety scores predicted self-handicapping scores. Self-concept clarity, 
test anxiety scores, academic self-efficacy and self-regulation were predictors of mid-term exam grades.

Previous studies have also shown that learners can not automatically know what strategies work best for them. For this reason, explicit strategy training, coupled with thinking about how one goes about learning and experimenting with different strategies, can lead to be more effective.

\section{Purpose and Significance of the Study}

In this study, learners' self-concept and language learning strategies were discussed. It was well known that the learners' self-concept would not only influence their choice of activities that they undertook, but also affect the amount of effort that they prepared to expend and their level of persistence. Language learning strategies also had an effect on language learning.

The main objective of this study was to reveal the characteristics of Chinese non-English majors in terms of their self-concept on English learning and the learning strategies they used, and to investigate the way gender influenced self-concept and LLSs. Moreover, it aimed at studying the relationship between self-concept and LLSs. With regard to the relations between English self-concept and language learning strategies, the findings of the research can be in line with the hypothesis that positive self-concept contributes significantly to learning strategies, and learners with high self-concept might use the learning strategies better than those with lower self-concept and thus achieve better performance.

The results of the study can contribute to a better understanding of English self-concepts Chinese college non-English majors hold about themselves in English learning, and thereby help teachers find effective ways to stimulate and enhance them. Demonstrating the relationship between self-concept and language learning strategies can subsequently lead to better performance in English.

To begin with, the study on relationship between self-concept and LLSs promotes a new perspective to research into LLSs and can enrich research on second/foreign language learning strategies and self-concept. In addition, the findings of this study might serve as a foundation for further studies on EFL strategy instruction and self-concept.

Second, this study can help Chinese non-key university English teachers better understand the characteristics of EFL students' self-concept and strategy use. The results on the relationship between self-concept and LLSs can instruct teachers to teach students different LLSs according to their self-concept. It is beneficial to EFL learning and teaching.

Third, the research might provide some theoretical implications for psychological research into the nature of self-concept.

All these considerations lead to the following research questions:

(1) What are the characteristics of Chinese non-English majors in terms of their self-concept on English learning and the learning strategies they use in English learning?

(2) If yes, what roles does gender play on the development of self-concept and on the use of specific strategies?

(3) What is the relationship between self-concept and learning strategies of Chinese non-English majors?

\section{Methodology}

The current study involved 157 students majoring in computer science and international trade and business in Shandong University of Finance. The sources of data of the study came from two questionnaires, one on English self-concept and the other is on language learning strategies. The questionnaire on self-concept is created by modifying the Academic Status Quo of High School Students (ASQHSS) developed mainly by Pan (2003) which itself is substantially based on the Self Description Questionnaire II (SDQII) by Marsh (1992). The second questionnaire is the measure of language learning strategies: SILL. All the items represent the concrete strategies used throughout the whole learning process rather than being associated with specific task (Cohen, 1998). The questionnaires were administrated during normal class time. Only two students did not respond to the questionnaires properly because of the contradiction. As a result, 155 questionnaires were valid and used for statistical analyses.

Before the statistical analyses were conducted, responses to all negatively worded items in English self-concept scale were first reversely scored so that higher scores reflected higher self-concept. Then the total scores of each subject's general English self-concept, English speaking self-concept, English pronunciation self-concept, were computed respectively. At the same time, the scores of each subject's learning strategies were put into the computer. Then all the related data were put into the computer and statistical analyses were conducted with SPSS 13.0.

As to the first research question, descriptive statistics was conducted to find out the overall situation of all participants' self-concept and learning strategies. Then an independent samples t-test was carried out to identify whether there were significant differences in the self-concept between males and females. Similar statistical procedures were used to analyze the data obtained from the SILL. Finally, the Pearson correlation and regression analysis were conducted to reveal whether there was a significant relationship between the self-concept and the use of learning strategies.

\section{RESULTS AND DISCUSSIONS}

A. Characteristics on Self-concept and LLSs 
As shown in Table 3.1, the mean scores (from 3.450 to 3.711) of both the specific and global measures of English self-concept indicated that Chinese college non-English majors did not hold high English self-concept. The mean scores of English pronunciation self-concept were found to be higher than those of English speaking self-concept and English general self-concept. So it meant that among the non-English major students' English self-concept, the level of English pronunciation self-concept was the highest, followed by the level of general English self-concept, and that of English speaking self-concept was the lowest.

The SPSS 13.0 was utilized to analyze the subjects' scores in the SILL. The discussion on each strategy set included the minimum, maximum, mean scores and standard deviation.

It was found that eleven strategy sets were categorized as the group of medium use. Among them, ten strategy sets belonged to memory, cognitive, social and affective strategies. This suggested that these strategies were used sometimes by the subjects. The strategies of overcoming limitations in speaking, centering one's learning, and self-evaluation obtained mean scores higher than 3.500, which meant these strategies were used frequently by the subjects (Table 3.2). It seemed that students in this college preferred to employ compensatory strategies and metacognitive strategies, because the mean scores of the two strategies were above 3.500. The compensation category had the highest mean scores. On the other hand, the mean scores of translation and transfer in cognitive strategy and cooperation in social strategy were all lower than 3. It indicated that these strategies were the least frequently used.

\section{B. The Effects of Gender on Self-concept and LLSS}

As shown in Table 3.3, the analysis provided convincing evidence that male and female learners differed in their global English, speaking and pronunciation self-concepts. The mean of females' general English self-concept (3.8000) was higher than that of males' (3.566). To a certain extent it meant that female learners had more positive general English self-concept than the male. And the means of females' specific-domain English self-concept were also higher than those of males, which implied that females had more positive English self-concept in the facets of speaking and pronunciation than males. However, there was only statistically significant gender difference in the pronunciation self-concept (As shown in Table 3.3, $\mathrm{p}=0.018<0.05$ ). It indicated that females' pronunciation self-concept was significantly higher than males. Therefore, by the statistical analysis, no substantial impacts of interaction could be observed on all dependent variables.

The independent samples t-test was used to examine the role of gender difference in learning strategies. Table 3.4 shows that the $P$ values of eleven strategy sets did not reach the significant level $(p<0.05)$ which indicated gender difference had a weak relation with learning strategies. But three strategy sets, as shown in Table 3.4, strongly relate to gender difference. Female students were found to more frequently use the strategies of centering one's learning, planning \& organizing and empathy than male students. Generally speaking, gender had no significant effects on LLSs.

\section{The Relationship between English Self-concept and LLSs}

In the study, the relationship between English self-concept and LLSs is the key question. Thus this part discussed the relationship in detail and by correlation analysis, more results were found.

1. Results of Correlation Analysis

In this study, Pearson correlation coefficients were computed to determine the degree of association between English self-concept and language learning strategies. General English self-concept, English speaking self-concept and English pronunciation self-concept had the highest correlations with the cognitive strategy, with values of $r=.523, r=.478$ and $\mathrm{r}=.384$ respectively. Among them, English pronunciation self-concept had the lowest correlations with the memory strategy $(r=.189)$ and compensatory strategy $(r=.220)$. General English self-concept had higher correlations with six language learning strategies, comparing with English speaking self-concept and English pronunciation self-concept. The matrix of correlation coefficients between English self-concept and language learning strategies was shown in Table 3.5, which showed that all of the correlations were considered to be statistically significant.

2. Results of Regression Analysis

In this study, the three aspects of English concept were treated as independent variables while the fourteen sets of strategies were considered as the dependent variables. That was to say, the fourteen sets of strategies were used as outcome measures in separate regression analyses, with the three aspects of English concept initially available to predict the language learning strategies. Results from Table 3.6 were seen as the powerful predictor on dependent variables. It showed that English general self-concept and two specific English self-concepts (speaking and pronunciation) were found to be significantly correlated with some language learning strategies.

Table 3.6 was just summary of the significant results of relationship between self-concept and language learning strategies. The author chose the four sets of learning strategies with the highest coefficients in three self-concepts respectively, because in each self-concept, highly-correlated strategy sets can specify the relationship between self-concept and language learning strategies.

As for general English self-concept, it correlated significantly to the strategies of centering one's learning, practicing, taking one's emotional temperature and planning \& organizing. First, among them, it had the highest relationship with strategies of centering one's learning (.525). General English self-concept referred to global understanding of his or her English ability or knowledge. Second, when students had high assessments to their global English level, they were willing to spend more time practicing to get their higher expectation. So the general English self-concept correlated 
significantly to practicing strategy (.515). Third, the strategies for taking one's temperature dealt with handling one's emotion state which included activities like writing diaries, sharing feeling with others and being aware of pressure on health. English learners, marked with a tendency for organizing and controlling, would use these strategies to minimize the influence from negative feelings. Finally, the planning and organizing strategies here referred to arranging a comfortable environment for learning, making plans ahead for weekly study and seeking personal goals in learning tasks. It was not surprised to see that students with the high general English self-concept would develop these strategies to arrange their own learning.

As for English speaking self-concept (ESSC), there were significant relationships between ESSC and the strategies of practicing, cooperation, encouragement, and overcoming limitations in speaking. Firstly, ESSC had highest correlation with practicing strategy (.520). Practicing was a good way to improve students' English speaking ability while students with high ESSC had more confidence to practice and had ability to put more time to practice. Secondly, strategy of cooperation was second highly correlated with ESSC (.442). When students with high consciousness in their English speaking were talking with people, they would naturally employ these strategies in communication. Thirdly, the strategies of encouragement dealt with taking some "reasonable" risks and then self-rewarding. Students who had high ESSC often put continuous effort because they determined to do the best. So they would use the strategies supporting their progresses in learning. Last but not least, if one student had high English speaking self-concept, it showed that he was confident in English speaking and could be satisfied with his speaking ability. So during talking with others, he could try his best to overcome limitations in his speaking and he would use some compensatory techniques such as inference, use of gesture and mother tongues that could help him temporarily narrow the gap of understanding or expressing in English.

Concerning English pronunciation self-concept (EPSC), it was significantly related to strategies of rehearsal, practicing, sending and receiving message and self-evaluation. To begin with, EPSC had a highest correlation with strategy of rehearsal (.435). In language leaning strategies, the rehearsal strategies concerned practicing spelling, pronunciation and getting familiar with useful expressions. Students with high EPSC would frequently use the strategies to develop a personal meaning in learning. Second, EPSC was correlated significantly to practicing strategies (.392). It was obvious that with the purpose in mind, students often actively sought for opportunity to read and practice. Third, the strategies for sending and receiving message mainly concerned building input and output structure which included activities like note taking, summarizing and outlining. Students with high EPSC would use the strategies of building structures for input or output. Finally, the strategies for self-evaluation concerned learning from one's mistakes and making progress in one's learning. Students who had high assessment of their English pronunciation would employ the strategies in correcting one's mistakes in coursework and seeking highest possible grades.

\section{CONCLUSION}

The study explored some characteristics of college non-English majors' self-concept and language learning strategies, and the relationship between self-concept and LLSs. But the present study was constrained by time and personnel. The analysis tools were not perfect and the perspectives concerned were not so complete. Therefore, the depth and width of the results were far from satisfactory. Despite the limitations, the present study has made an attempt to examine language learning strategies from a completely new perspective and has yielded enlightening findings. Subsequent studies are hoped to overcome the above-mentioned limitations and draw a more complete picture of it.

\section{Pedagogical Implications}

From the major findings, it was found that improving self-concept is a good way to develop students' language learning strategies because self-concept has positive correlation with language learning strategies. In order to improve use of learning strategies, college students should shape a positive self-concept which means to identify and admit self. It is also a way of perfecting and developing oneself.

Through the above research and result analysis, English teachers should pay more attention to help students develop their positive self-concept that can motivate their language learning strategies. First, English teachers should enhance the students' general English self-concept. Second, English teachers should not ignore importance of pronunciation teaching, especially the teachers who teach students at the early elementary stage of English learning. Last but not least, teachers can integrate language learning strategies into language instruction to influence the students' self-concept and their performances. In fact, it has become clear that language instruction should accommodate to students' learning through flexible teaching techniques and language teachers should be more sensitive to individual learners.

\section{APPENDIX}


TABLE 1.1

SUMMARY OF OXFORD'S (1990) LIST OF STRATEGIES

\begin{tabular}{|l|l|}
\hline Direct Strategies & Indirect Strategies \\
\hline Memory Strategies & 1.Metacognitive Strategies \\
Creating mental links or connections & A. Centering your learning \\
Applying images to sounds & B. Arranging and planning your learning \\
Reviewing well & C. Evaluating your learning \\
Employing action & \\
\hline Cognitive Strategies & 2. Affective Strategies \\
A. Practicing & A. Lowering your anxiety \\
B. Receiving and sending messages & B. Encouraging yourself \\
C. Analyzing and reasoning & C. Taking your emotional temperature \\
D. Creating structure for input \& output & \\
\hline Compensation strategies & 3.Social Strategies \\
Guessing intelligently & A. Asking questions \\
Overcoming limitations in speaking and writing & B. Cooperating with others \\
& C. Empathizing with others \\
\hline
\end{tabular}

TABLE 3.1

RESULTS OF DESCRIPTIVE ANALYSIS OF STUDENTS' SELF-CONCEPT

\begin{tabular}{|l|l|l|l|l|}
\hline Variables & Mean & Maximum & Minimum & SD \\
\hline GESC & 3.660 & 5.510 & 1.490 & .940 \\
\hline ESSC & 3.450 & 5.000 & 1.020 & .914 \\
\hline EPSC & 3.711 & 6.000 & 1.625 & .902 \\
\hline
\end{tabular}

Notes: GESC=General English Self-concept $\quad$ ESSC=English Speaking Self-concept $\mathrm{EPSC}=$ English Pronunciation Self-concept $\quad \mathrm{SD}=$ Standard Deviation

TABLE 3.2

RESULTS OF DESCRIPTIVE ANALYSIS OF STUDENTS' LLSS

\begin{tabular}{|c|c|c|c|c|c|c|}
\hline Categories & Strategy Sets & Items & Mini & Maxi & Mean & Std.Deviation \\
\hline \multirow{4}{*}{$\begin{array}{l}\text { Cognitive } \\
\text { Strategy }\end{array}$} & Rehearsal & 6 & 1.551 & 4.502 & 3.144 & 0.653 \\
\hline & Practicing & 4 & 1.807 & 5.000 & 3.204 & 0.708 \\
\hline & Sending and receiving message & 5 & 1.403 & 4.805 & 3.102 & 0.628 \\
\hline & Translation and transfer & 5 & 1.006 & 4.304 & 2.706 & 0.639 \\
\hline \multirow{2}{*}{$\begin{array}{l}\text { Memory } \\
\text { Strategy }\end{array}$} & Association & 6 & 1.337 & 4.406 & 2.682 & 0.621 \\
\hline & Structured review & 3 & 1.004 & 5.006 & 3.195 & 0.806 \\
\hline $\begin{array}{l}\text { Compensatory } \\
\text { Strategy }\end{array}$ & Overcoming limitations in speaking & 5 & 2.007 & 5.002 & 3.981 & 0.774 \\
\hline \multirow{3}{*}{$\begin{array}{l}\text { Metacognitive } \\
\text { Strategy }\end{array}$} & Centering one's learning & 2 & 1.005 & 5.006 & 3.543 & 0.731 \\
\hline & Planning and organizing & 5 & 2.003 & 5.006 & 3.358 & 0.644 \\
\hline & Self-evaluation & 3 & 1.401 & 5.003 & 3.656 & 0.735 \\
\hline \multirow{2}{*}{$\begin{array}{l}\text { Affective } \\
\text { Strategy }\end{array}$} & Encouragement & 2 & 1.508 & 5.002 & 3.410 & 0.904 \\
\hline & Taking one's temperature & 3 & 1.001 & 5.001 & 3.158 & 0.823 \\
\hline \multirow[t]{2}{*}{ Social Strategy } & Cooperation & 4 & 1.203 & 5.003 & 2.902 & 0.707 \\
\hline & Empathizing with others & 2 & 1.006 & 4.802 & 3.321 & 0.553 \\
\hline
\end{tabular}

TABLE 3.3

\begin{tabular}{|c|c|c|c|c|c|c|c|}
\hline & \multicolumn{6}{|c|}{ GENDER EFFECTS ON ENGLISH SELF-CONCEPT } & \multirow[b]{2}{*}{ Sig.(2-tailed) } \\
\hline & SEX & $\mathbf{N}$ & Mean & SD & $\mathbf{t}$ & df & \\
\hline \multirow[t]{2}{*}{ GESC } & 1 & 75 & 3.566 & .910 & -1.230 & 151 & .137 \\
\hline & 2 & 80 & 3.800 & 1.050 & & & \\
\hline \multirow[t]{2}{*}{ ESSC } & 1 & 75 & 3.310 & .900 & -1.003 & 151 & .108 \\
\hline & 2 & 80 & 3.621 & .960 & & & \\
\hline \multirow[t]{2}{*}{ EPSC } & 1 & 75 & 3.650 & .920 & 0.786 & 151 & .018 \\
\hline & 2 & 80 & 3.910 & .970 & & & \\
\hline
\end{tabular}

Notes: GESC=General English Self-concept $\quad$ ESSC=English Speaking Self-concept $\mathrm{EPSC}=$ English Pronunciation Self-concept $\quad 1=$ male, $2=$ female 
TABLE 3.4

RESULTS OF INDEPENDENT SAMPLES T-TEST ON GENDER DIFFERENCES

\begin{tabular}{|c|c|c|c|c|c|}
\hline \multirow[t]{2}{*}{ Categories } & \multirow[t]{2}{*}{ Strategy Sets } & \multicolumn{2}{|l|}{ Mean } & \multirow[t]{2}{*}{$\mathrm{T}$} & \multirow[t]{2}{*}{$\mathrm{P}$} \\
\hline & & Male & Female & & \\
\hline \multirow{4}{*}{$\begin{array}{l}\text { Cognitive } \\
\text { Strategy }\end{array}$} & Rehearsal & 3.093 & 3.441 & .332 & .765 \\
\hline & Practicing & 2.940 & 3.515 & 1.577 & .114 \\
\hline & Sending and receiving message & 3.001 & 3.302 & .485 & .628 \\
\hline & Translation and transfer & 2.607 & 3.104 & -.270 & .759 \\
\hline \multirow[t]{2}{*}{ Memory Strategy } & Association & 2.508 & 2.980 & .310 & .700 \\
\hline & Structured review & 2.984 & 3.402 & 1.674 & .096 \\
\hline Compensatory Strategy & Overcoming limitations in speaking & 3.773 & 4.307 & .044 & .970 \\
\hline \multirow{3}{*}{$\begin{array}{l}\text { Metacognitive } \\
\text { Strategy }\end{array}$} & Centering one's learning & 3.205 & 3.601 & 2.544 & $.009 *$ \\
\hline & Planning and organizing & 3.252 & 3.506 & 3.055 & $.004^{*}$ \\
\hline & Self-evaluation & 3.403 & 3.893 & 1.652 & .210 \\
\hline \multirow[t]{2}{*}{ Affective Strategy } & Encouragement & 3.502 & 3.201 & 1.962 & .054 \\
\hline & Taking one's temperature & 3.002 & 3.305 & 1.485 & .150 \\
\hline \multirow[t]{2}{*}{ Social Strategy } & Cooperation & 2.808 & 3.106 & .387 & .668 \\
\hline & Empathizing with others & 3.201 & 3.351 & 2.320 & $.022 *$ \\
\hline
\end{tabular}

Note: Levene's test for equality of variances (T and P) examines whether the grouping variable of gender (Female/Male) demonstrates difference on strategy sets.

TABLE 3.5

CORRELATION BETWEEN SELF-CONCEPT AND LLSS

\begin{tabular}{|l|l|l|l|l|l|l|}
\hline & $\begin{array}{l}\text { Cognitive } \\
\text { Strategy }\end{array}$ & $\begin{array}{l}\text { Memory } \\
\text { Strategy }\end{array}$ & $\begin{array}{l}\text { Compensatory } \\
\text { Strategy }\end{array}$ & $\begin{array}{l}\text { Metacognitive } \\
\text { Strategy }\end{array}$ & $\begin{array}{l}\text { Affective } \\
\text { Strategy }\end{array}$ & $\begin{array}{l}\text { Social } \\
\text { Strategy }\end{array}$ \\
\hline GESC & 0.523 & 0.310 & 0.340 & 0.464 & 0.396 & 0.430 \\
\hline ESSC & 0.478 & 0.231 & 0.300 & 0.354 & 0.365 & 0.356 \\
\hline EPSC & 0.384 & 0.189 & 0.220 & 0.276 & 0.284 & 0.280 \\
\hline
\end{tabular}

Notes: GESC=General English Self-concept $\quad$ ESSC=English Speaking Self-concept EPSC $=$ English Pronunciation Self-concept

TABLE 3.6

RESULTS OF REGRESSION ANALYSIS

\begin{tabular}{|l|l|l|}
\hline Self-concept & Strategy Sets & Standardized Coefficients \\
\hline \multirow{5}{*}{ GESC } & Centering one's learning & 0.525 \\
\cline { 2 - 3 } & Practicing & 0.515 \\
\cline { 2 - 3 } & Taking one's temperature & 0.486 \\
\cline { 2 - 3 } & Planning and organizing & 0.441 \\
\hline \multirow{5}{*}{ ESSC } & Practicing & 0.520 \\
\cline { 2 - 3 } & Cooperation & 0.442 \\
\cline { 2 - 3 } & Encouragement & 0.356 \\
\cline { 2 - 3 } & Overcoming limitations in speaking & 0.346 \\
\hline \multirow{5}{*}{ EPSC } & Rehearsal & 0.435 \\
\cline { 2 - 3 } & Practicing & 0.392 \\
\cline { 2 - 3 } & Sending and receiving message & 0.356 \\
\cline { 2 - 3 } & Self-evaluation & 0.330 \\
\hline
\end{tabular}

Notes: GESC=General English Self-concept $\quad$ ESSC=English Speaking Self-concept EPSC $=$ English Pronunciation Self-concept

\section{REFERENCES}

[1] Abraham, R. G., \& Vann, R. J. (1987). Strategies of two language learners: A case study. In A. Wenden, \& J. Rubin (Eds.), Learner strategies in language learning (pp. 85-102). Cambridge, England: Prentice-Hall International, Ltd.

[2] Bandura, A. (1986). Social foundations of thought and action. Englewood Cliffs, NJ: Prentice-Hall.

[3] Bialystok, E. (1981a). The role of linguistic knowledge in second language use. Studies in Second Language Acquisition, 4, 31-45.

[4] Bialystok, E. (1981b). The role of conscious strategies in second language proficiency. Canadian Modern Language Review, 35 , 372-394

[5] Bialystok, E. (1981). The role of conscious strategies in second language proficiency. Modern Language Journal, 65, 24-35.

[6] Bialystok, E. (1990). Communication strategies. Oxford: Blackwell.

[7] Behnaz, A. G., \& Ali, R. (2008). Language learning strategy use for EFL E-learners and traditional learners: A comparative study. International Journal of Instructional Technology and Distance Learning, 12, 3-22.

[8] Boersma, F. J., \& Chapman, J. W. (1992). Perception of ability scale for students. Los Angeles, CA: Western Psychological services.

[9] Bracken, B. A. (1996). Clinical applications of a multidimensional, context-dependent model of self-concept. In B. A. Bracken (Ed.), Handbook of self concept: Developmental, social, and clinical considerations (pp. 463-505). New York: John Wiley and Sons.

[10] Brown, H. D. (1994). Teaching by principles: An interactive approach to language pedagogy. Englewood Cliffs, NJ: 
Prentice-hall.

[11] Burns, R. B. (1979). The self-concept in theory, measurement, development and behavior. NY: Longman Press.

[12] Byrne, B. M. (1986). Self-concept/academic achievement relations: An investigation of dimensionality, stability, and causality. Canadian Journal of Behavior Science, 18, 173-186.

[13] Byrne, B. M. (1996). Academic self-concept: Its structure, measurement, and relation to academic achievement. In B.A. Bracken (Ed.), Handbook of self-concept (pp. 287-316). New York: Wiley.

[14] Chamot, A. U. (1987). The learning strategies of ESL students. In A. Wenden, \& J. Rubin (Eds.), Learner strategies in language learning (pp.71-83). Englewood Cliffs: Prentice Hall.

[15] Chamot, A. U., \& Kupper, L. (1989). Learning strategies in foreign language instruction. Foreign Language Annals, $22,13-24$.

[16] Cheng, X. \& Zheng, M. (2002). English learning strategies. Beijing: Foreign Language Teaching and Research Press.

[17] Cohen, A. D. (1990). Language learning: Insights for learners, teachers, and researchers. New York: Newbury House Publishers.

[18] Cohen, A. D. (1998). Strategies in learning and using a second language. Harlow, England: Longman.

[19] Cooley, C. H. (1902). Human Nature and the Social Order. New York: Scribner's.

[20] Coopersmith, S. (1967). The antecedents of self-esteem. San Francisco: W. H. Freeman.

[21] Crain, R. M. (1996). The influence of age, race, and gender on child and adolescent multidimensional self-concept. In B. A. Bracken (Ed.), Handbook of self-concept: Developmental, social, and clinical considerations (pp. 395-420). NY: John Wiley \& Sons, Inc.

[22] Ellis, R. (1990). Understanding second language acquisition. Oxford: Oxford University Press.

[23] Ellis, R. (1994). The study of second language acquisition. Oxford: Oxford University Press.

[24] Franken, R. (1994). Human motivation. Pacific Grove, CA: Brooks/Cole Publishing.

[25] Gage, N., \& Berliner, D. (1992). Educational psychology. Boston: Houghton Mifflin.

[26] Green, J. M., \& Oxford, R. L. (1995). A closer look at learning strategies, L2 proficiency and gender. TESOL Quarterly, 29 (2), 261-97.

[27] Hamachek, D. (1995). Self-concept and school achievement: Interaction dynamics and a tool for assessing the self-concept component. Journal of Counseling \& Development, 73 (4), 419-425.

[28] Harter, S. (1985). Manual for the self-perception profile for children. Denver, CO: University of Denver.

[29] Hattie, J., \& Marsh, H. W. (1996). Future directions in self-concept research. In B. A. Bracken (Ed.), Handbook of self-concept: Developmental, social, and clinical considerations (pp. 421-462). NY: John Wiley \& Sons, Inc.

[30] Hattie, J. (1992). Self-concept. Hillsdale, NJ: Erlbaum.

[31] Hattie, J., \& Mclnman, A. (1991). Gender differences in self-concept. Manuscript submitted for publication.

[32] Helmke, A., \& van Aken, M. A. G. (1995). The causal ordering of academic achievement and self-concept of ability during elementary school: A longitudinal study. Journal of Educational Psychology, 87, 624-637.

[33] Hismanoglu, M. (2000). Language learning strategies in foreign language learning and teaching. In Internet TESL Journal, 6 (8). Retrieved October 2008 from http://iteslj.org/Articles/ Hismanoglu-Strategies.html.

[34] Hou, S. (1998). Effects of tasks and gender on foreign language communication strategies. Journal of Pla University of Foreign Languages, 6, 20-25.

[35] Huang, X., \& van Naerssen, M. (1987). Learning strategies for oral communication. Applied Linguistics, 8 (3), 287-307.

[36] James, W. (1890). Principles of Psychology. Chicago: Encyclopedia Britannica.

[37] Jiang, P. (1997). Importance of self-concept in foreign language teaching. Foreign Languages Research, 3, 64-65.

[38] Jones, B. F. et al. (1987). Strategic teaching and learning: Cognitive instruction in the content areas. Elmhurst, IL: North Central Regional Laboratory and the Association for Supervision and Curriculum Development.

[39] Keith, L. K., \& Bracken, B. A. (1996). Self-concept instrumentation: A historical and evaluative review. In B. A. Bracken (Ed.), Handbook of self-concept: Developmental, social, and clinical considerations (pp. 91-170). NY: John Wiley \& Sons, Inc.

[40] Khaldieh, A. S. (2000). Learning strategies and writing processes of proficient vs. less-proficient Learners of Arabic. Foreign Language Annals, 33, 522-534.

[41] Lau, I. C. et al. (1999). Toward a hierarchical, multidimensional English self-concept. Journal of Educational Psychology, 91 (4), 747-755.

[42] Leino, A. (1982). Learning process in terms of styles and strategies. Research Bulletin No. 59. Helsinki, Finland.

[43] Li, Q. (2005). Self-concept and its correlation with English study. Dalian: Dalian University of Technology.

[44] Ma, D. (2003). English self-concept of Chinese college English majors. Guangdong: Guangdong University of Foreign Studies.

[45] MacIntyre, P. D. (1994). Toward a social psychological model of strategy use. Foreign Language Annals, 27, 185-195.

[46] Marsh, H. W. (1986). Verbal and math self-concepts: An internal/external frame of reference model. American Educational Research Journal, 23 (1), 129-149.

[47] Marsh, H. W. (1990). Influences of internal and external frames of reference on the formation of Math and English self-concepts. Journal of Educational Psychology, 82 (1), 107-116.

[48] Marsh, H. W. (1990). The structure of academic self-concept: The Marsh/ Shavelson model. Journal of Educational Psychology, $82(4), 623-636$.

[49] Marsh, H. W. (1992b). Self Descriptive Questionnaire (SDQ) I: A theoretical and empirical basis for the measurement of multiple dimensions of preadolescent self-concept. A test manual and research monograph. Macarthur, NSW Australia: Faculty of Education, University of Western Sydney.

[50] Marsh, H. W. (1992). The content specificity of relations between academic achievement and academic self-concept. Journal of Educational Psychology, 84, 43-50.

[51] Marsh, H. W. (2003). A reciprocal effects model of the causal ordering of academic self-concept and achievement. Paper presented at NZARE AARE, Auckland, New Zealand November, MAR03755.

[52] Marsh, H.W., \& Craven, R. G. (1997). Academic self-concept: Beyond the dustbowl. In G. Phye (Ed.), Handbook of classroom assessment: Learning, achievement and adjustment (pp. 131-198). San Diego, CA: Academic Press. 
[53] Marsh, H. W., \& Shavelson, R. J. (1985). Self-concept: Its multi-faceted hierarchical structure. Educational Psychologist, 20, $107-125$.

[54] Marsh, H. W., \& Yueng, A. S. (1997). Causal effects of academic self-concept on academic achievement: Structural equation models of longitudinal data. Journal of Educational Psychology, 89 (1), 41-54.

[55] Marsh, H. W., \& Yeung, A. S. (1998). Longitudinal structural equation models of academic self-concept and achievement: Gender differences in the development of Math and English Constructs. American Educational Research Journal, 35 (4), 705-738.

[56] Marsh, H. W., Byrne, B. M., \& Shavelson, R. J. (1988). Multifaceted academic self-concept: Relationships with inferred self-concept and academic achievement. Journal of Educational Psychology, 80, 366-380.

[57] Marsh, H. W., Byrne, B. M., \& Yueng, A. S. (1999). Causal ordering of academic self-concept and achievement: Reanalysis of a pioneering study and revised recommendations. Educational Psychologist, 34 (3), 154-167.

[58] Marsh, H. W., Relich, J. D., \& Smith, I. D. (1983). Self-concept: The construct validity of interpretations based upon the SDQ. Journal of Personality and Social Psychology, 45 (1), 173-187.

[59] Marsh, H. W., Smith, I. D., \& Barnes, J. (1985). Multidimensional self-concepts: Relations with sex and academic achievement. Journal of Educational Psychology, 77 (5), 581-596.

[60] Marsh, H. W., et al. (2002). Multilevel Causal Ordering of Academic Self-Concept and Achievement: Influence of Language of Instruction (English Compared With Chinese) for Hong Kong Students. American Educational Research Journal, 39 (3), 727-763.

[61] Naiman, N., Frohlich, M., Stern, H. H., \& Todesco, A. (1978). The Good Language Learner. Toronto: Ontario Institute for Studies in Education.

[62] Nisbet, D. L., Tindall, E. R., \& Arroyo, A. A. (2005). Language learning strategies and English proficiency of Chinese university students. Foreign Language Annals, 38, 100-107.

[63] Nunan, D. (1991). Language teaching methodology: A textbook for teachers. New York: Prentice Hall.

[64] Oerter, R. (1989). Structural, ecological, and psychological variables of schooling and their impact on the development of student's self-concept. International Journal of Educational Research, 13 (8), 933-948.

[65] O’Malley, J. M., \& Chamot, A. U. (1990). Learning strategies in second language acquisition. Cambridge: Cambridge University Press.

[66] Ommagio, H. A. (2001). Teaching language in context. Boston, MA: Heinle \& Heinle.

[67] Oxford, R. L. (1990). Language learning strategies: What every teacher should know. Boston, MA: Heinle \& Heinle Publishers.

[68] Oxford, R. L., \& Burry-stock, J. A. (1995). Assessing the use of language learning strategies worldwide with the ESL/EFL version of the Strategy Inventory for Language Learning (SILL). System, 23, 1-23.

[69] Oxford, R. L., \& Cohen, A. (1992). Language learning strategies: Crucial issues of concept of and classification. Applied Language Learning, 3, 1-35.

[70] Oxford, R. L., \& Nyikos, M. (1989). Variable affecting choice of language learning strategies by university students. Modern Language Journal, 73 (2), 291-300.

[71] Pan, C. (2003). Formation of English self-concept of Chinese adolescents: the role of English pronunciation and significant others. Guangdong: Guangdong University of Foreign Studies.

[72] Pan, W. (2003). English pronunciation self-concept: its effects on Chinese-speaking EFL learner. Guangdong: Guangdong University of Foreign Studies.

[73] Park, G. (1997). Language learning strategies and English proficiency in Korean University students. Foreign Language Annals, 30(2), 211-221.

[74] Politzer, R. L., \& McGroarty, M. (1985). An exploratory study of learning behaviors and their relationship to gains in linguistic and communicative competence. TESOL Quarterly, 19 (1), 103-123.

[75] Qing, X. (1998). Empirical research of English learning strategies used by graduates. Foreign Language Education, 1, 53-57.

[76] Rogers, C. R. (1951). Client-centered therapy. Boston: Houghton Mifflin.

[77] Rubin, J. (1987). Learning strategies: theoretical assumptions, research history and typology. In A. Wenden, \& J. Rubin (Eds.), Learner strategies in language learning (pp. 15-30). Englewood Cliffs, NJ: Prentice-Hall.

[78] Sarbin, T. R. (1952). A preface to a psychological analysis of the self. Psychological Review, 59, 11-22.

[79] Shavelson, R. J., \& Bolus, R. (1982). Self-concept: The interplay of theory and methods. Journal of Educational Psychology, 74, 3-17.

[80] Shavelson, R. J., Hubner, J. J., \& Keesling, J. W. (1980). Self-concept: Recent developments in theory and methods. New Directions for Testing and Measurement, 7, 25-43.

[81] Shavelson, R. J., Hubner, J. J., \& Stanton, G. C. (1976). Self-concept: Validation of construct interpretations. Review of Educational Research, 46, 407-441.

[82] Shi, Y. (1991). Study on learning strategies. Psychological Development and Education, 3, 55-58.

[83] Skehan, P. (1989). Individual differences in second language learning. London: Edward Arnold.

[84] Skehan, P. (1991). Individual differences in second language learning. SSLA, 13, 275-98.

[85] Stern, H. H. (1975). What can we learn from the good language learner. Canadian Modern Language Review, $34,304-18$.

[86] Stern, H. H. (1983). Fundamental concepts of language teaching. Oxford: Oxford University Press.

[87] Strein, W. (1993). Advances in research on academic self-concept: Implications for school psychology. School Psychology Review, 22, 273-284.

[88] Thomas, C. R. \& Gadbois, S. A. (2007). Academic self-handicapping: The role of self-concept clarity and students' learning strategies. The British Journal of Educational Psychology, 3, 101-19.

[89] Vispoel, W. P. (1995). Self-concept in artistic domains: An extension of the Shavelson, Hubner, and Stanton (1976) model. Journal of Educational Psychology, 87 (1), 134-153.

[90] Waltz, G. R., \& Bleuer, J. C. (1992). Students' self-esteem: A vital element of school success. Ann Arbor, MI: Counseling and Personnel Services. 
[91] Wang, C. (2004). Self-concept, English pronunciation and EFL learning. Foreign Language Teaching and Research, 1, 57-63.

[92] Wang, C. (2004). A study on the relationship between English pronunciation self-concept and actual pronunciation. Foreign Language World, 5, 62-67

[93] Wang, C., \& Qi, L. (1992). A case study of English listening strategies. In S. Gui (Ed.), English learning psychology of Chinese students (pp. 102-121). Changsha: Hunan Education Publishing House.

[94] Wang, L. (1998). Language learning strategies and foreign language teaching. Foreign Language research, 2, 64-66.

[95] Wang, L. (2002). An experiment on teaching of communication strategies to Chinese EFL learners. Foreign Language Teaching and Research, 6, 426-430, 480.

[96] Watkins, D. \& Gerong, A. (1999). Language of response and the spontaneous self-concept: A test of the cultural accommodation hypothesis. Journal of Cross-Cultural Psychology, 30, 115-121.

[97] Weinstein, C, E., \& Mayer, R. E. (1986). The teaching of learning strategies. In M.C. Wittrock (Ed.), Handbook of research on teaching (pp. 315-327). New York: Macmillan.

[98] Wenden, A., \& Rubin, J. (1987). Learner strategies in language learning. Englewood Cliffs, NJ: Prentice Hall.

[99] Wenden, A. (1991). Learner strategies for learner autonomy: planning and implementing learner training for language learners. Englewood Cliffs, NJ: Prentice Hall.

[100] Wen, Q. (1996). English learning Strategies. Shanghai: Shanghai Foreign Language Education Press.

[101] Wen, Q., \& Johnson, R. K. (1997). L2 learner variables and English achievement: a study of tertiary-level English majors in China. Applied Linguistics, 18 (1), 27-48.

[102] Wen, Q., \& Wang, H. (1996). Research on English learning belief and learning strategies of college students. Journal of Pla University of Foreign Languages, 4, 61-66, 75.

[103] Wen, Q., \& Wang, L. (2003). Empirical research on English learning strategies. Xian: Shaanxi Normal University Publishing House.

[104] Wen, Q., \& Wang, L. (2004). Theoretical research on English learning strategies. Xian: Shaanxi Normal University Publishing House.

[105] William, E. T., \& James, W. C. (2002). The relation of beginning readers' reported word identification strategies to reading achievement, reading-related skills, and academic self-perceptions. Reading and Writing: An Interdisciplinary Journal, 15, 341-358.

[106] Wu, B. (2002). English learning strategies. Beijing: People's Education Press.

[107] Wu, Y., Liu, R., \& Jeffrey, P. (1993). Learner factors and language learning achievement: A survey. Foreign Language Teaching and Research, 1, 36-46, 80.

[108] Wu, Z. (1994). Learner strategies: A key factor in second language learning. Modern Foreign Languages, 3, $22-27$.

[109] Wylie, R.C. (1979). The self-concept (Vol.2). Lincoln: University of Nebraska Press.

[110] Xu, J., \& Zhao, J. (2006). Correlation between English self-concept and language learning strategies among medical students. Northwest Medical Education, 14 (1), 68-70.

[111] Yang, H. (2004). Self-concept \& college English teaching: An investigation of some college English learners at Guangxi Normal University. Guangxi: Guangxi Normal University.

[112] Yang, Y. (2006). The effect of self-concept on foreign language learning. Dalian: Dalian Maritime University.

[113] Yeung, A. S., \& Lee, F. L. (1999). Self-concept of high school students in China: Confirmatory factor analysis of longitudinal data. Educational and Psychological Measurement, 59, 431-450.

[114] Zhang, Z. (2005). English self-concept of Chinese college non-English majors: Its relations to self-attributions to success and failure in English learning. Jilin: Jilin University.

[115] Zhuang, Z., \& Shu, D. (1994). The study of L2 learner strategies and its implications for FLT. Modern Foreign Languages, 3 , $28-32,72$.

Mingmei Du was born in Chengdu, China in 1980. She received her M.A. degree in linguistics from Shandong University, China in 2009 .

She is currently a lecturer in the School of Foreign Languages, Shandong University of Finance, Jinan, Shandong, China. Her research interests include second language acquisition, cognitive linguistics and teacher development.

Ms. $\mathrm{Du}$ is a member of Chinese Teacher Association and has attended and completed 2009' Beijing Foreign Studies University-University of Auckland PhD Preparatory Program. 